\title{
The Coaching of Family Welfare and Empowerment Group of Krueng Barona Jaya through the Making of Soap
}

\author{
Mirna Rahmah Lubisa), Husni Husin, Lia Mairiza, and Yoessi Oktarini \\ Jurusan Teknik Kimia, Universitas Syiah Kuala, Banda Aceh, Indonesia \\ a)Corresponding Author: mirna@che.unsyiah.ac.id
}

\begin{abstract}
The Krueng Barona Jaya is a sub-district in Aceh Besar District, Aceh Province, Indonesia. This subdistrict is located near the Ulee Kareng area, Banda Aceh. The Krueng Barona Jaya sub-district has at least more than 16,000 people spread across a number of locations. Most of the residents in Krueng Barona sub-district earn their living as farmers, domestic workers, civil servants, entrepreneurs, and $31.53 \%$ have temporary jobs. This situation can be improved by providing various training to residents to help them establish their own or group businesses. The community service activity is intended to improve public understanding about technology of making liquid soap. To achieve this objective the team sincerely helped provided training on the process of making liquid soap for mothers in the family-welfareempowerment group. The results of interviews with the community and sub-district officials showed that the women of the group were very enthusiastic in participating in soap making training and other similar activities. The results of interviews with the community and sub-district officials showed that the women of the group were very enthusiastic in participating in soap making training and other similar activities. The results of the discussion indicated that the participants' mastery of making soap was very good. This training and coaching opens people's mind to change their habits and thinking patterns.
\end{abstract}

Keywords: Deodorizer, dye, liquid soap, sodium chloride, texapon N70

\section{INTRODUCTION}

Krueng Barona Jaya sub-district has a sub-district office in Ceurih Village, which can be reached by using a small public transportation called "labi-labi" with a distance of about four kilometres in 15 minutes. This sub-district has three villages called Lamreung, including Meunasah Papeun, Lueng le Village, and Meunasah Baktrieng. Lamreung is also famous as the hometown of one of Aceh's national figures named Teuku Nyak Arief who is buried in the area. In addition, there are also three villages known as Lam Ujong, namely: Meunasah Intan Village, Meunasah Baet Village, and Meunasah Manyang. The total population of Krueng Barona Jaya sub-district in 2019 was 17,091 people, consisting of 3,906 households with 8,762 male and 8,329 female gender.

This sub-district has an agricultural area with a planting area of 213 hectares and plantations with a harvested area of 242 hectares. Currently, the livelihoods of the residents of Krueng Barona Jaya District are quite diverse. The majority of residents have a livelihood in the form of farmers and ranchers $(31.82 \%)$, civil servants $(20.72 \%)$, self-employed $(16.67 \%)$, and $31.53 \%$ have irregular or unclear jobs. This is caused by the low level of education of the sub-district population. Krueng Barona Jaya is one of the sub-district where several villages receive budget assistance from Community Based Settlement Environmental Management (CBSEM). The budget is expected to increase development in Aceh Besar District, Krueng Barona Jaya Subdistrict. The community was very enthusiastic to hear the explanation of the officers from Aceh Besar District about the budget assistance from the CBSEM.

This community generally still find it difficult to get a job because the skills possessed by the population are lacking. This situation can be overcome by providing various trainings to residents so that they can set up their own businesses or in groups. The form of training provided is easy to understand and the products can be used as small and medium industries. The head of the Family Empowerment and Welfare (FEW) group has asked the Community 
Service Team from Universitas Syiah Kuala (USK) to provide training to FEW women, Krueng Barona Jaya Sub-district.

One of the skills that can be given is the process of introduction, training, and making liquid soap. Liquid soap was chosen because it has the advantages of being easy to make, cheap in raw materials, and needed by all people from rural to urban areas. Soap is a material made from natural oils that react with sodium hydroxide in a process known as the saponification reaction (Head, 1995). Conventional soap is a product of the saponification process between fat or oil with a mixture of alkalis to form salts of fatty acids that have amphipathic properties (Adiwibowo, 2020). If soap comes into contact with grease or oil that soils clothing, the hydrophobic ends of the anions become fat soluble. Micelles emulsify the oil and hold it in suspension so that it can be carries away by the water rinse (Brady, 1994). Negative ions in soap hydrocarbons will bind to fats while carboxylic acids in fats will bind to water so that dirt will be carried away from the surface of the soapy material (Adaku and Melody, 2013). Due to the repulsion between soap and oil droplets, these oils cannot blend together but remain suspended (Fessenden, 1992). Soap can act as an emulsifier (Poedjiadi, 2004). Soap uses additives for various purposes such as for beauty and medicine so that it can increase its selling value (Widyasanti et al., 2016). This soap additive contains vitamins, relatively high anti-oxidant components such as beta-carotene with the function of restoring skin cells (Agustina et al., 2017), papain components in papaya which can help regenerate skin, and antiseptic content that can prevent body odour (Sari et al., 2019).

The term tension, which is well-known in Europe, is a word that originally had more technical meaning to name the working process of soap ingredients, which is active at surface tension (tension), but in other countries it is usually referred to as surfactant (Wasitaatmadja, 1997). The solubility of ionic surfactants in water will be optimum in the $C 12$ chain (Salanger, 2002). Anionic surfactants commonly used as LAS (linear alkyl benzene sulfonates) and ABS (alkyl benzene sulfonates) (Apriyani, 2017). Liquid soap quality requirements referring to SNI 06-4085-1996 are shown in Table 1.

The problem faced by the FEW group in Krueng Barona Jaya Sub-district as a forum for housewives is related to the limited skills in finding business opportunities. The problem for the residents of Krueng Barona Jaya District is the lack of mastery of technology and the difficulty of getting a job that can cover the needs of their family life. In addition to low education, the population also lacks interest in acquiring knowledge and skills from other places regarding skills and ways of doing business. Based on the two categories, Krueng Barona Jaya Sub-district was chosen as the area for community service activities.

Based on the results of this activity, residents are expected to be able to understand and apply the knowledge they have learned in their daily lives. Residents can increase their knowledge about the simple technology of making liquid soap. This activity can improve the standard of living of the community and as a solution and alternative in solving economic problems that are currently engulfing the community. This appropriate technology can be disseminated to the public.

\section{METHOD}

The Community Service Team from USK has held discussion with the Chair and Management of the FEW Group in Krueng Barona Jaya Sub-district (Figure 1). In line with the formulation of the problem, the solution was taken through the preparation of materials, preparation of tools, training, and hands-on practice by 20 participants. The training is intended to provide knowledge about a simple way of making liquid soap to be used as a home industry. The material used will be explained in its origin and amount. This method of making liquid soap is still new to them. Therefore, this service program can also be a pioneer for new entrepreneurs. The manufacture of liquid soap is expected to help create new businesses to small industries. The activity stages include socialization, preparation of materials and tools, 
training activities, as well as testing and using soap for washing. A statement letter has been made between the implementers of the Science and Technology Program activities of Higher Education at Universitas Syiah Kuala and the FEW Group, Krueng Barona Jaya Sub-district. The formulation of the problems to be solved and the implementation of training activities at various levels lasts for four months.

\section{Soap Making Coaching}

The methods applied to this service are interviews, coaching, direct training, discussions, and evaluations to participants to produce liquid soap products. The main targets in this science and technology activity are FEW women in Krueng Barona Jaya Sub-district who are members of the sub-district FEW group and low-income communities. After being equipped with basic knowledge, the participants were then given the opportunity to make liquid soap. The results of the trial are then presented for deliberation and are then ready to be disseminated in the surrounding environment. For participants who are interested in starting a business, they will continue to be monitored if there are problems in its implementation. This target group is then expected to spread this knowledge and skills to other residents around Aceh Besar in particular and the Aceh Region as a whole.

\section{Main Ingredients for Making Soap}

The materials used are:

\section{Texapon $\mathrm{N} 70$}

Texapon N70 which has other names sodium laureth sulphate (SLS), sodium lauryl ether sulphate (SLES), or sodium lauryl sulphate N70 is usually used in household cleaning products (floor, cat shampoo, dish washing, powder detergent, gel soaps, hair shampoos, and shower gels. This material is a material that produces foam and is required as much as one kilogram.

\section{Sodium chloride}

This compound is also known as salt or table salt. It is an ionic compound with the formula $\mathrm{NaCl}$. This compound is a salt that is largely responsible for the saltiness of marine and extracellular solutions, commonly used as a seasoning and food preservative. Salt is needed 150 grams.

\section{Lemon scented fragrance}

It functions as an additive that will not reduce the quality of liquid soap. The addition of perfume can attract consumers' attention to liquid soap so that it will be easier if it is sold. The fragrance used is usually lemon or apple scented so that it is easier to remove the impurity smell to be cleaned, it takes $20 \mathrm{ml}$.

4. Distilled water 17 liters

5. Green dye six grams

6. Fixative (scent enhancer) $20 \mathrm{ml}$

7. Technical Carboxymethyl Carbon (CMC) 250 grams

\section{Dish Soap Recipe}

At present, the majority of people use liquid soap to wash dishes (Hartatik and Indriyani, 2013). Dish soap has certain characteristics such as binding grease and removing dirt without scratching the glass (Figure 2). This material should have foaming properties like detergent. Conventional powder detergents consists of phosphates, silicates, and other alkalis. However, powdered detergents have a certain disadvantage, which is to cause spots and streaks, especially when these detergents are used for hard water areas. The disadvantage of detergents is that the solid constituents dissolved in hard water are difficult to measure.

The method of making it is:

1. Water 15 litres is prepared into the basin.

2. Texapon is added and stirred gently with a wooden spoon so that the foam does not become excessive. 
3. The CMC mixture was prepared by blending it with water until it was evenly mixed and put into the texapon solution.

4. The table salt, fragrance, and fixative are stirred until homogeneous.

5. Packaged bottles are prepared, the solution is put into packaged bottles, labelled, and ready to be marketed.

\section{RESULTS}

The making of liquid soap is carried out at the Meeting Hall of the Krueng Barona Jaya Subdistrict office, Aceh Province, Aceh Besar District. The service activities carried out included several stages as follows: 1) Coordination with the sub-district head, 2) Preparation of coaching, 3) Implementation of coaching, 4) Implementation of training, and 5) Evaluation and follow-up. The results of interviews with the community showed that they were enthusiastic about participating in this training.

Based on the monitoring results of the service team, it is clear that enthusiasm of the community is high, which can be measured by the number of participants in the socialization and training, as well as the many questions that arise during the practice of making liquid soap. The participants increasingly realized that making liquid soap can be done easily and the ingredients are simple.

\section{DISCUSSION}

Surveys and assessments of village resources were conducted to obtain data on efforts to use local commodities and village constraints. The coordination of the service team was carried out with the partner of the Chairperson of the FEW Group, Krueng Barona Sub-district. In this activity, the partners and the service team discussed about the service activities to be carried out, the time and place for implementation of coaching and training. At the meeting there were several agendas that were discussed, namely the socialization of service activities, time, place, and permission to conduct coaching and training in making liquid soap. During the discussion, it was decided that the raw material for making soap is texapon, which is affordable.

This is because FEW women are very easy to obtain and so far their use has not been known. One of the efforts to increase the added value of texapon is to process it into liquid soap. The synthetic liquid soap that will be made has advantages, such as low price, contains CMC which is easily soluble in cold water, and does not contain harmful chemicals, such as triclosan, soap, preservatives, parabens, polyethylene glycol, and methyl-isothiazolinone. The coaching preparations carried out included coordinating between team members for the division of tasks, providing raw materials and complementary materials, buying equipment for soap training activities, planning liquid soap formulations, conducting trials of making liquid soap on campus, and compiling hand-outs of soap manufacturing steps. The need for tools for making liquid soap is presented in Table 2. The coaching activities carried out were in the form of measuring liquid soap recipes and making coaching and training hand-outs. The coaching hand-out contains general material on entrepreneurship and home industry opportunities, the basic principles of soap making, packaging, and selling soap. The training hand-out contain tools, materials, and methods of making liquid soap. To prepare for the training, the team conducted a trial run of the recipe for the synthesis of liquid soap products to obtain the right composition and provide optimal results.

The results of interviews with the community and sub-district officials showed that FEW women in Krieng Barona Jaya Sub-district were enthusiastic in participating in soap making training and other similar activities. The instructor in this coaching is Prof. Husni Husin as chairman of the Service Team. Before starting the coaching, the chairperson provided tools and told the training participants to make the process of making liquid soap run smoothly and gradually. The participants who have obtained the material knowledge about liquid soap then get directly involved in making liquid soap. Evaluation of activities was carried out through filling 
out a questionnaire by FEW mothers to find out the extent of their response to the activities that had been carried out. The things that are reviewed are the opinions and responses of mothers about the implementation of the liquid soap making training. The results of the questionnaire showed that the participants were very happy with the service activities because the participants had never received coaching and training on home industry opportunities in the form of liquid soap, the coaching and practice materials delivered were easy to understand and practice on their own, the materials for making liquid soap were easy to obtain, and the timing of the activities does not coincide with household activities. Participants are also enthusiastic and interested in exploring further so that they are able to become entrepreneurs themselves. This evaluations is followed by observation, identification, and compilation of additional data needed by the participants. These results will be used as material for participant in discussion activities with the USK Service Team to strengthen mastery of the material that has been given.

Based on the results of the discussion, it was indicated that the participants' mastery of soap making was very good. This is because the process of making soap is simple. In this discussion, the implementation team inserts materials that need to be mastered by the participants as input in preparing for future business. The service team in addition to delivering material on how to make liquid soap, also explained various possibilities that could be developed through the use of liquid soap and how to manage it to increase household income.

Based on the monitoring results of the service team, it is clear that the enthusiasm of the community is high, which can be measured by the number of participants in the socialization and training, as well as the total questions that arise during the practice of making liquid soap. The participants increasingly realized that making liquid soap can be done easily and the ingredients are simple. The resulting liquid soap can be developed more broadly, for example at a village party and expanded to a side business level.

The positive impact that appears is the empowerment of the people of Krueng Barona Jaya who do not work by providing knowledge on how to make soap. Another important impact is the handling of village community problems in creating good and economical job opportunities, and at the same time increasing their family income. The activity of making liquid soap does not include marketing.

The production is only for the needs of the FEW mothers' homes. This activity is carried out so that FEW members can be more independent and develop the potential of FEW mothers. Mothers who previously could not make liquid soap are now able to apply it themselves. With this activity program, mothers are able to make liquid soap at home and fulfil their need without buying them at the market. With this training, FEW members are able to utilize the skills they already have so that mothers can be more creative.

\section{CONCLUSIONS AND RECOMMENDATIONS}

This training and coaching opens people's minds to change their habits and mind-set in order to explore their potential to create new businesses. The community is expected to be able to make liquid soap to be used in their daily need. The training on making liquid soap for the FEW women's group has been successful. Soap products can be used as a source of business to increase their income. This coaching activity can be a technique for developing broad community empowerment within the framework of creating additional employment opportunities while at the same time generating additional income for the community.

\section{ACKNOWLEDGMENTS}

The service team would like to thank the Family Empowerment and Welfare Group in Krueng Barona Jaya Sub-district which provided financial assistance, support from lecturers in the Chemical Engineering Department of USK (Universitas Syiah Kuala) and Dr. Ir. Komala Pontas who contributed in the preparation of the report. 


\section{REFERENCES}

Adaku, U., \& Melody, M., (2013), Soap Production Using Waste Materials of Cassava Peel and Plantation Peel Ash as An Alternative Active Ingredient, Implication for Entrepreneurship, IOSR Journal of VLSI and Signal Processing, 3(3), 2319-4197.

Adiwibowo, M.T., (2020), Aditif Sabun Mandi Berbahan Alami: Antimikroba dan Antioksidan, Jurnal Integrasi Proses, 9(1), 29-36.

Agustina, L., Yulianti, M., Shoviantari, F., \& Sabban, I.F., (2017), Formulasi dan Evaluasi Sabun Mandi Cair dengan Ekstrak Tomat (Solanum lycopersicum L.) sebagai Antioksidan, Jurnal Wiyata Penelitian Sains dan Kesehatan, 4(2), 104-110.

Apriyani, N., (2017), Penurunan Kadar Surfaktan dan Sulfat dalam Limbah Laundry, Media IImiah Teknik Lingkungan, 2(1), 37-44.

Badan Standarisasi Nasional, (2017), Sabun Mandi Cair, SNI 06-4085-1996, Jakarta, Dewan Standardisasi Nasional.

Brady, J., (1994), Kimia Universitas, Jilid 1, Jakarta, Penerbit Erlangga.

Fessenden, F., (1992), Kimia Organik, Jilid Dua, Jakarta, Erlangga.

Hartatik, M., \& Indriyani, R., (2013), Pengelolaan dan Pengembangan Aspek Sumber Daya pada Usaha Pembuatan Sabun Krim di Perusahaan Keluarga UD. Airmas, AGORA, 1(1), 111.

Head, S.W., (1995), Small Scale Vegetable Oil Extraction, Great Britain: Natural Resources Institute.

Poedjiadi, A., (2004), Dasar-dasar Biokimia, Jakarta, Erlangga.

Salanger, J.L., (2002), Surfactants Types and Uses, De Los Andes, Laboratory of Formulating Interface Rheologi and Process.

Sari, S.A., Firdaus, M., Fadilla, N.A., \& Irsanti, R., (2019), Studi Pembuatan Sabun Cair dari Daging Buah Papaya (Analisis Pengaruh Kadar Kalium Hidroksida terhadap Kualitas Sabun), TALENTA Conference Series, 2(1), 60-67.

Wasitaatmadja, (1997), Penuntun IImu Kosmetik Medik, Jakarta, UI-Press.

Widyasanti, A., Farddani, C.L., \& Rohdiana, D., (2016), Pembuatan Sabun Padat Transparan Menggunakan Minyak Kelapa Sawit (Palm Oil) dengan Penambahan Bahan Aktif Ekstrak the Putih (Camelia Sinensis), Jurnal Teknik Pertanian Lampung, 5(3), 125-136.

\section{APPENDIX}

Table 1. Liquid Soap Quality Requirements

\begin{tabular}{cll}
\hline No & \multicolumn{1}{c}{ Test Variables } & \multicolumn{1}{c}{ Condition } \\
. & & \multicolumn{1}{c}{ Distinctive } \\
1. & Smell & Homogeneous \\
2. & Form & Solution \\
3. & Color & Distinctive \\
4. & Acidity $25^{\circ} \mathrm{C}$ & $8-11$ \\
5. & Free alkaline (\%) & Maximum 0.1 \\
6. & Active components (\%) & Minimum 15 \\
7. & Density, $25^{\circ} \mathrm{C}$ & $1.01-1.10$ \\
8. & Microbial & contamination \\
& (koloni/g) & Maximum $10^{4}$ \\
\hline
\end{tabular}

Table 2. Equipment Needs for Making Liquid Soap

\begin{tabular}{cc}
\hline Tool Name & Quantity \\
\hline Digital balance & 1 piece \\
\hline
\end{tabular}




\begin{tabular}{ll}
\hline Measuring cup & 1 piece \\
Pots/Basins & 2 pieces \\
Ordinary glass & 1 piece \\
Beater whisk/stirrer & 1 piece \\
Liquid soap holder & 1 set \\
Gloves & 1 box \\
Plastic packaging & 1 set \\
\hline
\end{tabular}

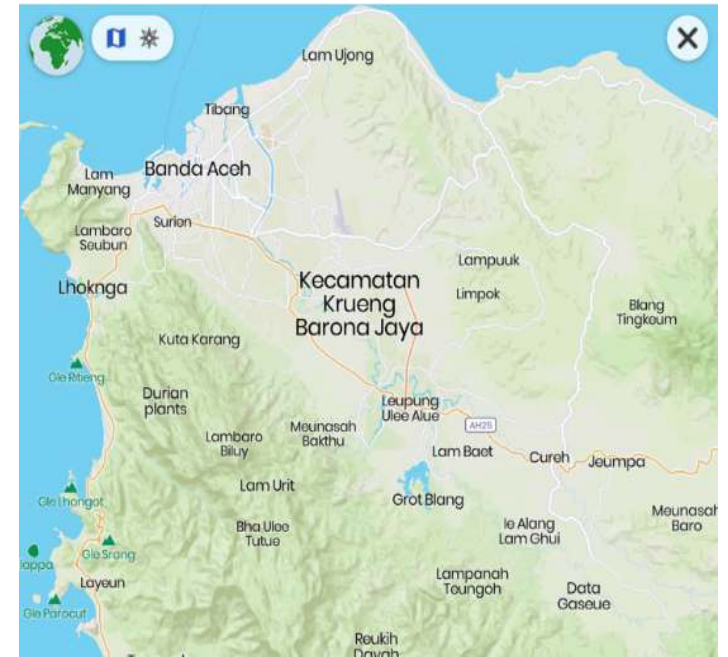

Figure 1. Map of Krueng Barona Jaya Subdistrict in Aceh Besar District

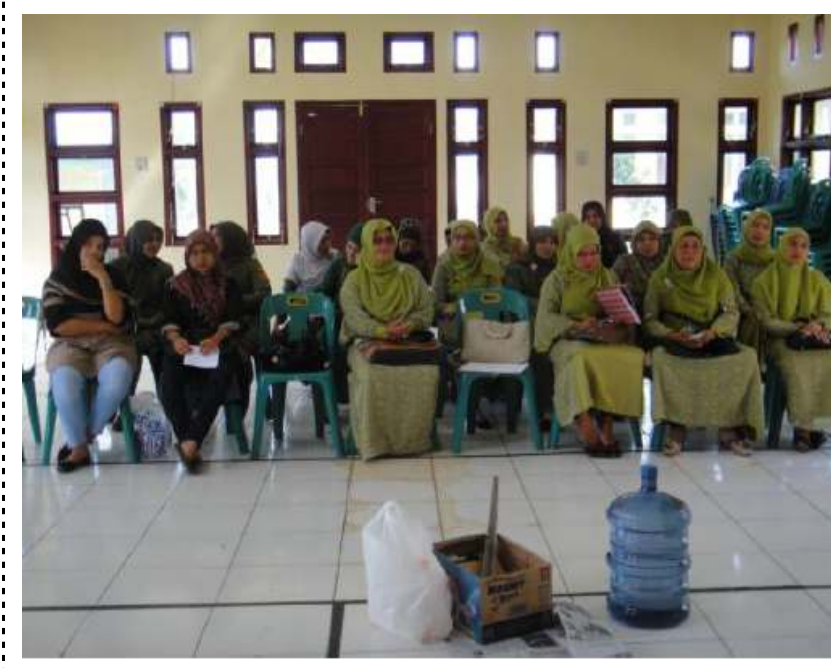

Figure 3. The FEW Group Team is Participating in Coaching on the Soap Making Process

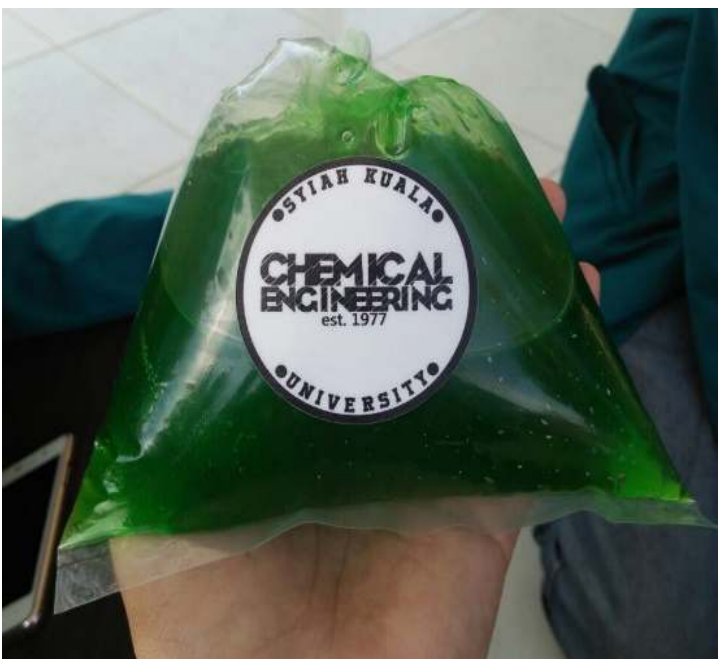

Figure 2. Dish Soap Products

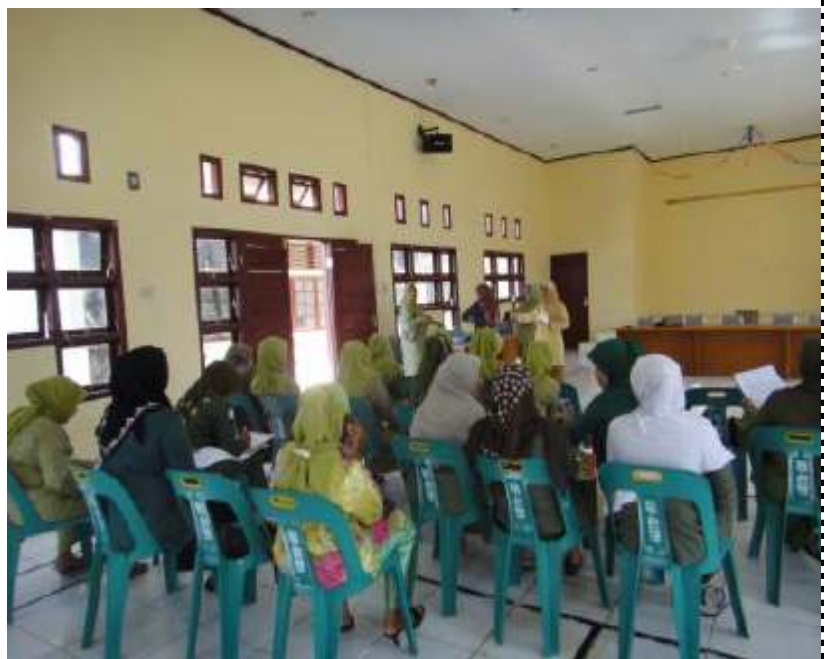

Figure 4. Introduction to Theory, Materials, and Working Methods 


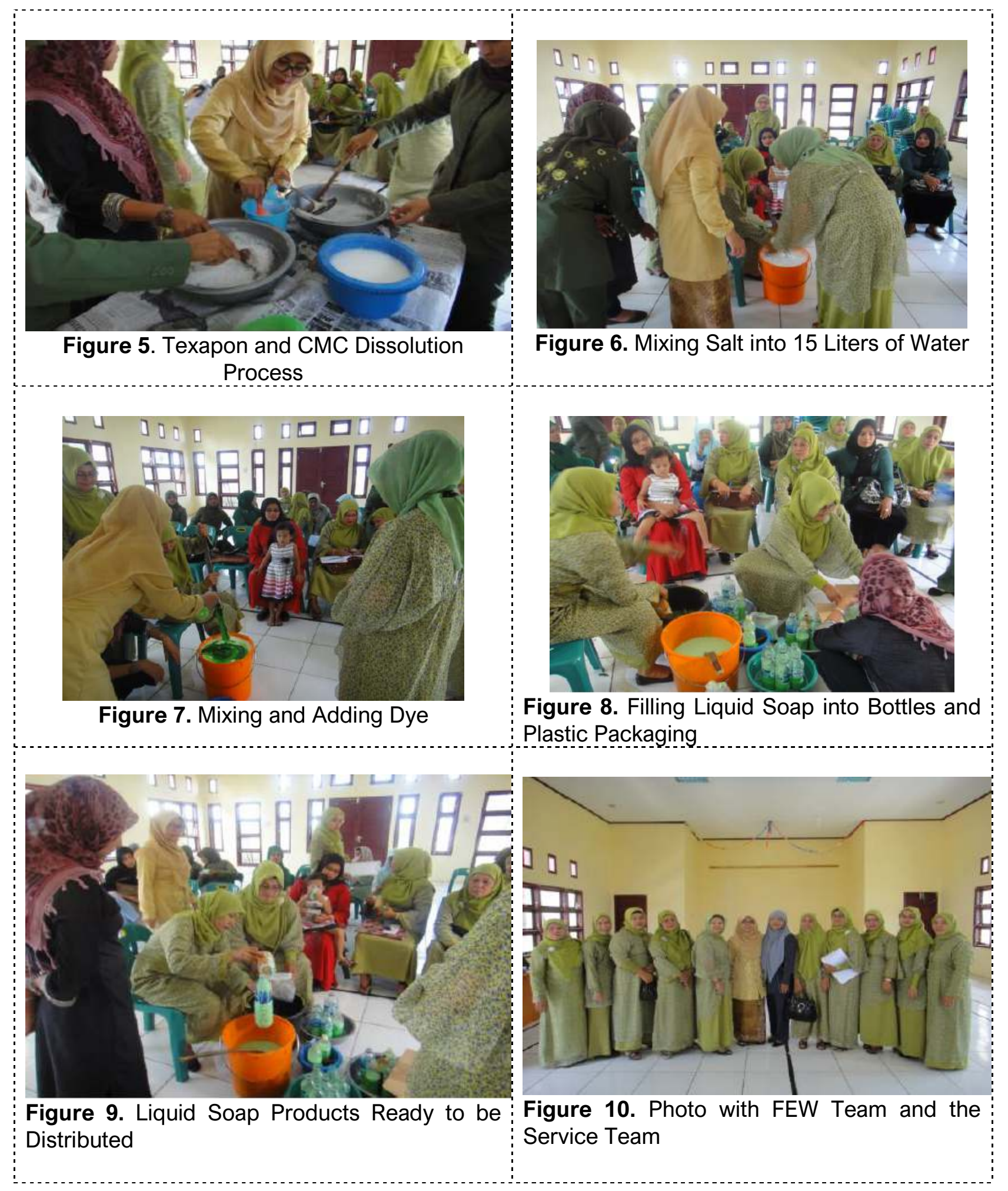

